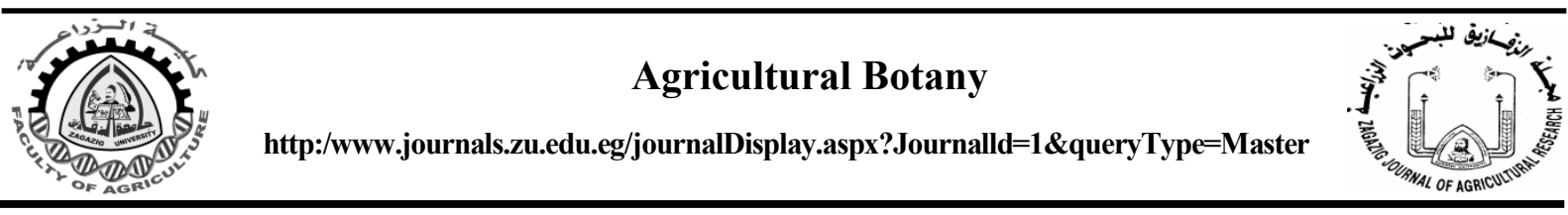

\title{
SALINITY STRESS AMELIORATION USING HUMIC ACID AND MYCORRHIZAE ON PEPPER PLANTS
}

\author{
Naser M. El-Sarkassy", Seham A. Ibrahim and E.M. Desoky \\ Agric. Bot. Dept., Fac. Agric., Zagazig Univ., Egypt
}

Received: 10/9/2017; Accepted: 30/10/2017

\begin{abstract}
Salinity is destructive factor and one of various abiotic stresses which strongly affects crop productivity and limits marketable yield of vegetable crops, for example pepper plants. This work studied the effects of sole application of each of Humic Acid (HA) and Arbuscular Mycorrizal Fungi (AMF), Glomus fasciculatum inoculation and their combinations in order to reduce the harmful effects of salinity stress on growth, yield and endogenous bio-constituents in pepper cultivar top star. Growth parameters at 75 days after transplanting and yield components were decreased under levels of salt stress (2000 or $4000 \mathrm{ppm}$ ). Applied of humic acid and mycorrhizae, partially counteracted the harmful effects of salinity stress levels. By increasing salt stress levels, proline, peroxidase and catalase activities and $\mathrm{Na}$ content were increased, but photosynthetic pigments in leaves and N, P, K content in shoots of pepper plants were decreased. In addition, all treatments of humic acid and mycorohizae either alone or in combination under different salt stress levels, slightly increased the content of proline, N, P, K and photosynthetic pigments, peroxidase and catalase activities while, $\mathrm{Na}$ content was decreased in pepper plants. It was observed that, the interaction between humic acid and mycorohizae increased the positive effect of mycorohizae inoculation. Results indicated also that, mycorrhizal inoculation help in ameliorating the damage caused by salt stress conditions in pepper plants. Application of humic acid combined with mycorrhizae, promote much more plant growth. These results provide support for the field application of humic acid and mycorrhizae to decline the harmful effects of salty soils.
\end{abstract}

Key words: Pepper, Capsicum annuum, salt stress, symbiosis agents, mycorrhizae, bio-stimulants, humic acid.

\section{INTRODUCTION}

Pepper (Capsicum annuum L.) is an important vegetable crop, because of its economic importance, and nutritional value. Pepper fruits are an excellent source of bioactive products. Salinity is among the major constrains restricting the growth and development of plants (Martínez et al., 2014 and 2015).

Under protected glasshouse conditions, Kijne (2003) reported that, pepper is grown in temperate regions and in the open field under warm Mediterranean climates. It is often exposed to salinity conditions brought about by widespread use of irrigation containing trace amounts of salts including sodium chloride. Fahramand et al. (2014) showed that, salinity stress is the major factor of abiotic stress which affect approximately every side of biochemistry and physiology of a plant, resulting in a reduction in its yield. Salts in soil or water had adverse effects on agriculture, because it causes a stress condition to crop plants. Salt-affected soil is one of the severe abiotic stresses that reason a reduction in development, plant growth and productivity worldwide (Sheng et al., 2011). Most commonly, salt stress caused by high amount of $\mathrm{Na}^{+}$and $\mathrm{Cl}^{-}$. Salt stress has three-fold effects which causes ion imbalance on disturbances in ion homeostasis and toxicity and reduces water potential. This altered water status

\footnotetext{
*Corresponding author: Tel.: +201004109568

E-mail address:desoky_s@yahoo.com
} 
leads to limitation of plant productivity and initial growth reduction. Salt stress affects some major processes such as germination, growth and chlorophyll content (Paridam and Das, 2005). Under salinity stress, Al-Sobhi et al. (2006) noticed that, the decreased in chlorophyll content is a commonly reported phenomenon and in various studies, because of its harmful effects on membrane stability. With increasing salinity stress, the increase of proline content was significantly higher in leaves than in roots (Beltrano et al., 2013).

In most cases, the adverse effects of salinity have been attributed to increase in $\mathrm{Na}^{+}$and $\mathrm{Cl}^{-}$ ions in different plants, hence these ions produce the critical conditions for plant survival by interrupting different plant mechanisms. Although both $\mathrm{Na}^{+}$and $\mathrm{Cl}^{-}$are the major ions, $\mathrm{Cl}^{-}$is the most dangerous, which produce many physiological disorders in plants (Tavakkoli et al., 2010).

The conclusion of salinity effects may cause nutrients imbalance, membrane damage, enzymatic inhibition, altered levels of growth regulators and metabolic dysfunction, including photosynthesis which eventually leads to plant death (Hasanuzzaman et al., 2012). Under salinity stress in pepper plants, Saker et al. (2012) reported that photosynthetic pigments, N, $\mathrm{P}$ and $\mathrm{K}$ contents were decreased, whilst increasing proline and $\mathrm{Na}$ contents.

The use of bio-stimulants to plants include humic substances as humic acid leads to positive metabolic changes, higher content of nutrients in plant tissue (Nardi et al., 2016). The plants that grow in soils containing sufficient amounts of humic acid are less stressed because of the humic substances are an important component of soil organic matter and shows anti-stress effects. (Hanafy et al, 2010).

Effects of arbuscular mycorrhizal (AM) symbiosis showed that, it could be improving plant tolerance to biotic and abiotic stresses, improving uptake of low mobile ions, improving quality of soil structure and soil nutrient cycling, improving rooting and plant establishment, (Smith and Read, 2008). Rouphael et al. (2015) showed that, arbuscular mycorrhizal (AM) fungi are obligate biotrophs that have a mutualistic association with the majority of the plants. For the plant partner, they play different useful roles i.e. mitigation of drought and salinity stresses, bio-regulation, bio-fertilization, and bioprotection. Beltrano et al. (2013) indicated that, the mycorrhizal inoculation ameliorated the damage caused by salinity stress conditions on pepper plants. Highlight the significance of arbuscular mycorrhizal fungi mitigation of salt stress and their beneficial effects on plant growth and productivity (Porcel et al., 2012)

Hashem et al., (2015) reported that, on cowpea growth parameters, AMF ameliorated the negative influence of salinity stress which enhanced the activity of antioxidant enzymes such as catalase (CAT), peroxidase (POD) and also, AMF inoculation further improved their activity, thus strengthening the defense system of plants. In salt stressed plants as well as AMFinoculated plants providing efficient protection against salt stress, proline content increased. Also AMF increased uptake of mineral elements which have direct effect on the osmoregulation of the plants. To some extent, AMF has been considered as bio-ameliorations of saline soils (Rao, 1998). The importance of AMF due to its great capability on the increase in yield of pepper and plant growth under certain conditions. Major reason for this increase in yield and the growth can be attributed to ability of plants in relations with AMF to uptake some nutrients efficiently, such as phosphorous. (Demir, 2004)

The soil application of either humic acid (HA) or arbuscular mycorrhizal fungi (AMF) could be relatively successful in attaining some salinity levels. Therefore, this work aimed to evaluate the impact of dual application of humic acid as bio stimulants and mycorrhiza as symbiosis agents on salinity stress and ameliorate the harmful effects of salinity stress on pepper growth parameters, yield and its endogenous bio-constituents.

\section{MATERIALS AND METHODS}

Two pot experiments were carried out during two successive growing seasons 2014 and 2015 under greenhouse conditions at the Experimental Station, Faculty of Agriculture, Zagazig University, Sharkia Governorate, Egypt, to study the response of certain phytochemical constituents, growth and yield of pepper plant to different levels of salinity stress, and how to 
ameliorate its harmful effects through application of humic acid as bio stimulant and mycorrhizae as symbiosis agents.

\section{Plant Materials and Experimental Conditions}

In this study, seeds of pepper (C. annuum L.) cv top star provided by Sacata Co. Cairo, Egypt. Seeds were sown on $28^{\text {th }}$ February in both seasons, seedlings were transplanted after 45 days (6-7 leaves) from sowing into plastic pots (50 $\mathrm{cm}$ inner diameter and $25 \mathrm{~cm}$ in depth). Each pot filled with $15 \mathrm{~kg}$ of air dried loamy soil and contained two plants.

\section{Mycorrhizal Inoculation}

Two kg of arbuscular mycorrhizal inoculation (Glomus fasciculatum) were mixed with $100 \mathrm{~kg}$ sand soil. The inoculation obtained from plant pathology Research Institute, Agriculture Research Center, Giza, Egypt. Then the pots were inoculated with using $5 \mathrm{~g}$ of inoculum per pot placed at $5 \mathrm{~cm}$ depth. After inoculation, a thin layer of soil was added, then the pots were planted and covered with soil. Control plants received mycorrhiza free inoculum. After planting the pots were subjected to salinity stress. Irrigation solutions containing one of 3 levels of sodium chloride $\mathrm{NaCl}$ were used: 320 ppm as control; 2000 ppm as conc. 1; 4000 ppm as conc.2; Irrigation solutions were supplied daily according to plant need and to maintain a slight reserve of water on the pot saucer. Before planting, the soil was treated with; humic acid at the rate of $10 \mathrm{~g}$ per pot as bio-stimulant and mycorrhiza as symbiosis agents at $5 \mathrm{~g}$ of inoculum per pot.

According to the recommendations by Egyptian Ministry of Agriculture and Land reclamation, all agricultural practices were conducted as follow: fertilizers were applied to each pot of growing pepper plant, nitrogen $(\mathrm{N})$ fertilizer in the form of ammonium sulphate $(20.5 \% \mathrm{~N})$ at the rate of $2.5 \mathrm{~g}$ per pot, phosphorous (P) fertilizer as calcium superphosphate $(15.5 \%$ $\left.\mathrm{P}_{2} \mathrm{O}_{5}\right)$ at the rate of $1.5 \mathrm{~g}$ per pot and potassium $(\mathrm{K})$ as potassium sulphate $\left(\mathrm{K}_{2} \mathrm{O}\right)$ at the rate of 1 $\mathrm{g}$ per pot were mixed with the soil before planting. Also, $\mathrm{N}$ (ammonium sulphate 20.5\% $\mathrm{N})$ added at 30, 60, and 120 days after transplanting at the rate of $1.5 \mathrm{~g}$ per pot.
In a complete randomized design, each experiment included 3 salinity levels and 4 applications of humic acid and mycorrhiza (12 treatments) replicated 6 times.

In both growing seasons, at 75 days after transplanting, three pots/sample were taken from each treatment and the following vegetative growth characters of pepper plant were recorded: plant height $(\mathrm{cm})$; number of leaves/ plant; leaf area $\left(\mathrm{cm}^{2} /\right.$ plant); and shoot dry weight $(\mathrm{g}) /$ plant. Three pots were taken from each treatment and the yield components of pepper plant were recorded: number of fruits/ plant (Total fruit yield); fresh weight of fruits/ plant (g); dry weight of fruits/ plant (g). From each treatment at 180 , and 210 days from transplanting, two fruit picking were taken and total fruit yield was calculated as summation of the two-fruit picking).

The following biochemical constituents of pepper plant namely: photosynthetic pigments; proline content; catalase and peroxidase activities were estimated in leaves and nutrient element contents: such as nitrogen, phosphorus, potassium and sodium contents were estimated in shoots of pepper plant.

\section{Determination of Photosynthetic Pigments}

Fresh leaf samples were used for estimation of Photosynthetic pigments as described by Wettestein (1957), and then calculated as $\mathrm{mg} / \mathrm{g}$ fresh weight.

\section{Determination of Proline}

Proline was estimated due to the following method of Bates et al. (1973). Approx. $0.5 \mathrm{~g}$ of leaf fresh weight (FW) were homogenized in 10 $\mathrm{ml}$ of $3 \% \quad(W / V)$ aqueous solution sulphosalicylic acid and filtered. Two $\mathrm{ml}$ of the filtrate was reacted with $2 \mathrm{ml}$ of acid ninhydrin, followed by the addition of $2 \mathrm{ml}$ of glacial acetic acid and boiled for 1 hour at $100^{\circ} \mathrm{C}$. The mixture was extracted with toluene and free proline was quantified spectrophotometrically at $520 \mathrm{~nm}$ absorbance from the organic phase.

Proline cocenteration was calculated per unit of FW according to: $\mu$ mols proline $\mathrm{g}^{-1} \mathrm{FW}=$ $[(\mu \mathrm{g}$ proline $/ \mathrm{ml} \times \mathrm{ml}$ toluene $) / 115.5 \mu \mathrm{g} /$ $\mu \mathrm{mols}] /(\mathrm{g} \mathrm{FW} / 5)$. 


\section{Determination of Catalase and Peroxidase Activity}

\section{Enzyme extraction}

The extraction was carried out according to the method reported by Vitoria et al. (2001). Collected fresh leaf samples were transported in an ice-box and brought to the laboratory. The leaves were washed with distilled water and wiped out of surface moisture and $0.5 \mathrm{~g}$ of leaves was homogenized in ice cold $0.1 \mathrm{M}$ phosphate buffer $(\mathrm{pH} 7.5)$ containing $0.5 \mathrm{mM}$ EDTA with pre-chilled mortar and pestle. Then transferred the homogenate to centrifuge tubes and was centrifuged at $4^{\circ} \mathrm{C}$ in Beckman refrigerated centrifuge at $15000 \times \mathrm{g}$ for $15 \mathrm{~min}$. The supernatant was transferred to $30 \mathrm{ml}$ tubes and referred to enzyme extract.

Catalase (CAT)Was assayed spectro-photochemically according to Chance and Maehly (1955). The enzyme extract $(100 \mu 1)$ was added to $100 \mu \mathrm{l}$ of $100 \mathrm{mM} \mathrm{H}_{2} \mathrm{O}_{2}$ and the total volume was made up to $1 \mathrm{ml}$ by $250 \mathrm{mM}$ - phosphate buffer $\mathrm{pH}$ (6.8). The decreasing in optical density at $240 \mathrm{~nm}$ against blank was recorded every minute.

Peroxidase (POD) activity was estimated due to the method of Thomas et al. (1982). The enzyme was assayed using guaiacol as the substrate. The reaction mixture was consisted of $3 \mathrm{ml}$ of phosphate buffer $(0.1 \mathrm{M}, \mathrm{pH} 7.0), 30 \mathrm{ml}$ of $\mathrm{H}_{2} \mathrm{O}_{2}(20 \mathrm{mM}), 50 \mathrm{ml}$ of enzyme extract and $50 \mathrm{ml}$ of guaiacol $(20 \mathrm{mM})$. The reaction mixture was incubated in a cuvette for $10 \mathrm{~min}$ at room temperature. The optical density was measured at $436 \mathrm{~nm}$ and the enzyme activity was expressed as number of absorbance unitsg ${ }^{-1}$ fresh weight of leaves.

\section{Determination of minerals contents}

$\mathrm{N}, \mathrm{P}, \mathrm{K}$ and $\mathrm{Na}$ in shoot pepper plant: Total nitrogen $(\mathrm{N})$ was determined colorimetrically using Nesslar solution according to the method described by Naguib (1963). Total phosphorus (P) was determined colorimetrically by the hydroquinone method as described by Snell and Snell (1954). Total potassium (K) and sodium $\mathrm{Na}$ ) contents were estimated by flame photometry (Peterburgski, 1968).

\section{Statistical Analysis}

The data of all experiments were analysed statistically using analysis of variance according to Gomez and Gomez (1984). The treatment means were compared using the least significant differences (LSD).

\section{RESULTS AND DISCUSSION}

\section{Plant Growth Parameters}

Results presented in Table 1 show that all growth parameters of pepper plants including plant height, leaf area, number of leaves and shoot dry weight were significantly decreased with exposure pepper plants to salinity stress levels (2000 ppm and $4000 \mathrm{ppm})$, the greatest reduction was noticed at $4000 \mathrm{ppm}$ of salinity at 75 days after transplanting. On the other hand, application of humic acid and mycorrhiza alone or in combination gave positive effect and led to growth improvements at all levels of salt stress and therefore acting as growth stimulants. In this case, it's likely to mention that any of each of humic acid and mycorrhiza could be counteracted the harmful effect of salt stress levels (2000 ppm and $4000 \mathrm{ppm}$ ) which enhanced all growth parameters of pepper plant under high salinity levels.

Humic acid + mycorrhiza treatment achieved the best protection against salt stress at $4000 \mathrm{ppm}$ and improved plant height, shoot dry weight, leaf area and number of leaves/plant. From the results of the present work, it is obvious that salt stress reduced plant growth characters of pepper plants. However, humic acid and mycorrhiza alone and their combination ameliorated the harmful effect of salt stress on the growth parameters.

The effect of salt stress levels and soil application by humic acid and mycorrhiza and their combination on total fruit yield and fresh, dry weights of pepper plant fruits observed in Table 2. As for salt stress levels, it could be clearly indicated that total fruits yield and fresh, dry weights of pepper fruits were significantly reduced by increasing the level of salt concentration.

In the present work, pepper plants subjected to salinity stress levels (2000 ppm and 4000 ppm) showed a clear reduction in all morphological 
Table 1. Effect of humic acid and arbuscular mycorrhizal fungi (AMF) and their combination on growth characters of pepper plant under salinity stress (average of two growing seasons 2014 and 2015)

\begin{tabular}{|c|c|c|c|c|c|c|c|c|}
\hline \multicolumn{9}{|c|}{ Salinity levels } \\
\hline & Control & Conc.1 & Conc. 2 & Mean & Control & Conc.1 & Conc. 2 & Mean \\
\hline & \multicolumn{4}{|c|}{ Plant height $(\mathrm{cm})$} & \multicolumn{4}{|c|}{ No. of leaves/plant } \\
\hline Control & 49.50 & 46.90 & 41.23 & 45.877 & 60.83 & 40.50 & 32.50 & 44.612 \\
\hline HA & 50.37 & 48.13 & 46.77 & 48.420 & 64.17 & 47.33 & 37.33 & 49.613 \\
\hline AMF & 45.27 & 48.50 & 47.74 & 47.168 & 68.33 & 47.83 & 43.33 & 53.168 \\
\hline $\mathbf{H A}+\mathbf{A M F}$ & 50.89 & 49.37 & 48.55 & 49.602 & 71.17 & 55.33 & 50.67 & 59.058 \\
\hline Mean & 48.378 & 47.843 & 45.243 & & 64.447 & 45.223 & 37.723 & \\
\hline \multirow[t]{2}{*}{ LSD at $0.05 \%$} & \multicolumn{4}{|c|}{$\begin{array}{c}\text { HAM: } 0.575 \quad \text { Salt: } 0.498 \\
\text { Interaction: } 0.996\end{array}$} & \multicolumn{4}{|c|}{$\begin{array}{c}\text { HAM: } 2.034 \text { Salt: } 1.762 \\
\text { Interaction: } 3.524\end{array}$} \\
\hline & \multicolumn{4}{|c|}{ Leaf area $\left(\mathrm{cm}^{2}\right) /$ plant } & \multicolumn{4}{|c|}{ Shoot dry weight (g)/plant } \\
\hline Control & 3248.84 & 1189.92 & 567.07 & 1668.6 & 9.30 & 6.74 & 4.20 & 6.745 \\
\hline HA & 3710.12 & 1873.78 & 975.89 & 2186.5 & 12.87 & 7.79 & 7.12 & 9.258 \\
\hline AMF & 4299.84 & 2090.65 & 1353.07 & 2581.1 & 13.56 & 8.14 & 6.95 & 9.547 \\
\hline $\mathbf{H A}+\mathbf{A M F}$ & 4615.23 & 2593.28 & 1938.55 & 3049.0 & 14.10 & 8.87 & 7.43 & 10.130 \\
\hline Mean & 3752.92 & 1718.11 & 965.34 & & 11.907 & 7.557 & 6.087 & \\
\hline LSD at $0.05 \%$ & \multicolumn{4}{|c|}{$\begin{array}{c}\text { HAM: } 214.96 \quad \text { Salt: } 186.16 \\
\text { Interaction: } 372.32\end{array}$} & \multicolumn{4}{|c|}{$\begin{array}{r}\text { HAM: } 0.359 \quad \text { Salt: } \\
\text { Interaction: } 0.622\end{array}$} \\
\hline
\end{tabular}

HA: Humic acid. AMF: Arbuscular mycorrhizal fungi. HAM: Humic acid and /or Arbuscular mycorrhizal Control: 320 ppm, Conc.1: 2000 ppm, Conc.2: 4000 ppm

Table 2. Effect of humic acid and arbuscular mycorrhizal fungi (AMF) and their combination on yield of pepper plant under salinity stress (average of two growing seasons 2014 and 2015)

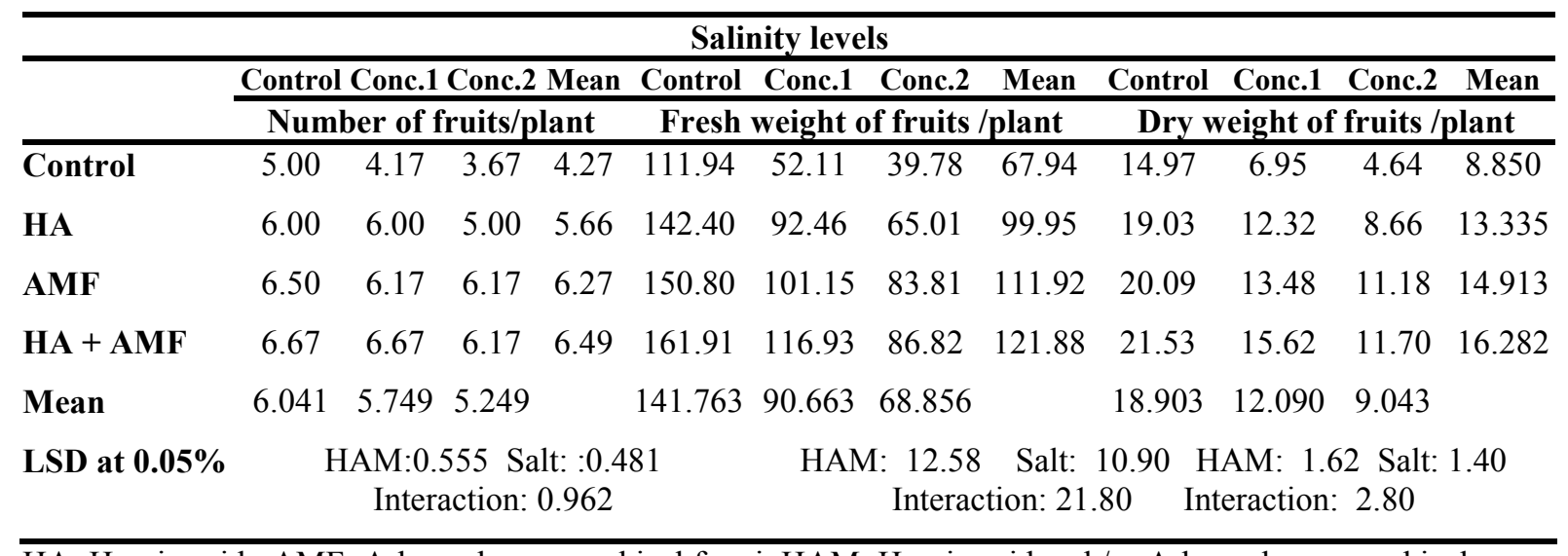

HA: Humic acid. AMF: Arbuscular mycorrhizal fungi. HAM: Humic acid and /or Arbuscular mycorrhizal Control: 320 ppm, Conc.1: 2000 ppm, Conc.2: 4000 ppm 
parameters and yield of pepper plant including plant height; number of leaves; leaf area; shoot dry weight; number of fruits/ plant (Total fruit yield); fresh and dry weight of fruits/plant $(\mathrm{g})$. These reductions may be due to the inhibition of cell division and cell elongation exerted by the high salinity levels (Aroca et al., 2013; Ahanger et al., 2014). Salinity in soil or water irrigation is of increasing importance to agriculture because it causes a stress condition to crop plants. Salt-affected soil is one of the dangerous abiotic stresses that cause a reduction plant growth, productivity worldwide and development (Sheng et al., 2011).

Furthermore, Sakr et al. (2007) noticed that the reduction in leaf area index caused reduction in the supply of carbon assimilates which causes a decrease in the net photosynthetic rate and biomass accumulation. On the other hand, salt stress significantly decreased plant height, root and shoot weights, total biomass, and leaf number. However, leaf area was not affected by salt stress. Dolatabadian et al. (2011) concluded that salinity stress decreased photosynthetic pigments and potassium uptake, all of which will ultimately decrease pepper yield. Sakr et al. (2004) reported that a reduction in fruit yield are largely attributable to decreases in the viability of pollen or the receptivity of the stigmatic surface and substantially increased flowers or young fruit abscission due to ethylene induction by salinity.

On the other hand, soil application of humic acid and mycorrhiza and their combination increased total fruit yield, fresh and dry weights of pepper fruit averaged during the two growing seasons. HA + mycorrhiza treatment was the most effective where it increased fruit yield more than the other two-treatments compared to the untreated plants (control). All of the biostimulant and symbiosis agents counteracted the negative effects of $2000 \mathrm{ppm}$ of salt stress and partially offset the effects of $4000 \mathrm{ppm}$ of salt stress. Also, it could be noticed that the combination between HA + mycorrhiza was the most effective in this respect.

The improving effect of humic acid on amelioration of drought or salinity stress may be through a stimulation of germination and plant growth and vigour of seed by accelerated cell division, increasing the rate of development in root systems, (Clapp et al., 2002). Porcel et al. (2012) emphasized the significance of arbuscular mycorrhizal fungi amelioration of salinity stress and their useful effects on plant growth and productivity. Mycorrhizal inoculated plants grown under salinity conditions experienced increase in root length, weights of fresh and dry shoots and content of photosynthetic pigments observed by Shekoofeh and Sepideh (2011). Selvakumar and Thamizhiniyan (2011) suggest the general results that mycorrhizal colonization improves host plant mineral concentration and thereby alters fruit production and quality of fruits under salinity stress in chilli plants.

\section{Biochemical Constituents}

The results in Table 3 clearly show that chlorophyll a, b and carotenoids in the fresh leaves of pepper plants were significantly reduced by salinity stress treatments $(2000 \mathrm{ppm}$ and $4000 \mathrm{ppm}$ ).

From the mentioned results, it could be concluded that photosynthetic pigments were increased under low salinity level of $\mathrm{NaCl}$, thereafter decreased with increasing salinity level, these reductions supported by the results reported by Arafa et al. (2014) who reported that photosynthetic pigments were significantly increased thereafter decreased by increasing of salinity levels. The obtained results concerning the effect of salinity stress on photosynthetic pigments in pepper leaves, it was significantly decreased with increasing salinity levels and this reduction may be related to enhanced activity of the chlorophyll-degrading enzyme, chlorophyllase, as suggested by Saha et al. (2010). The decrease in Chl contents under salinity stress is a generally reported phenomenon in various studies and the Chl concentrations were used as a sensitive indicator of the cellular metabolic state (Chutipaijit et al., 2011). In the present study, salinity decreased carotenoid content due to degradation of $\alpha$-carotein and formation of zeaxanthin, which protect the plant against photo inhibition (Sharma and Hall, 1991).

However, soil application with humic acid and mycorrhiza alone or in combination caused considerable increase in the photosynthetic pigments in the leaves of pepper plants compared with control treatment. Furthermore, the results showed that HA as bio stimulants and mycorrhiza as symbiosis agents 
Table 3. Effect of humic acid and arbuscular mycorrhizal fungi (AMF) and their combination on Photosynthetic pigments of pepper plant under salinity stress (average of two growing seasons 2014 and 2015)

\begin{tabular}{|c|c|c|c|c|c|c|c|c|}
\hline & \multicolumn{8}{|c|}{ Salinity levels } \\
\hline & Control & Conc.1 & Conc.2 & Mean & Control & Conc.1 & Conc.2 & Mean \\
\hline & \multicolumn{4}{|c|}{ Chl. A (mg/g) } & \multicolumn{4}{|c|}{ Chl. B (mg/g) } \\
\hline Control & 1.017 & 0.772 & 0.499 & 0.763 & 0.769 & 0.619 & 0.348 & 0.579 \\
\hline HA & 1.052 & 0.879 & 0.552 & 0.828 & 0.812 & 0.652 & 0.440 & 0.634 \\
\hline AMF & 1.074 & 0.954 & 0.717 & 0.915 & 0.846 & 0.704 & 0.539 & 0.696 \\
\hline HA + AMF & 1.181 & 0.960 & 0.725 & 0.955 & 0.898 & 0.742 & 0.589 & 0.743 \\
\hline Mean & 1.081 & 0.891 & 0.623 & & 0.831 & 0.679 & 0.479 & \\
\hline LSD at $0.05 \%$ & Chl. A & $\begin{array}{r}\text { M: } 0.09 \\
\text { Intera } \\
\text { B (mg/g) }\end{array}$ & $\begin{array}{l}9 \\
\text { ction: }\end{array}$ & lt: 0.086 & \multicolumn{4}{|c|}{$\begin{array}{rr}\text { HAM: } 0.059 \quad \text { Salt: } 0 \\
\text { Interaction: } 0.103 \\
\text { Carotenoids }(\mathbf{m g} / \mathbf{g})\end{array}$} \\
\hline Control & 1.313 & 1.391 & 0.847 & 1.183 & 0.232 & 0.199 & 0.141 & 0.191 \\
\hline HA & 1.397 & 1.531 & 0.992 & 1.306 & 0.244 & 0.204 & 0.156 & 0.201 \\
\hline AMF & 1.577 & 1.657 & 1.255 & 1.496 & 0.249 & 0.212 & 0.175 & 0.212 \\
\hline $\mathbf{H A}+\mathbf{A M F}$ & 1.686 & 1.702 & 1.313 & 1.567 & 0.262 & 0.230 & 0.192 & 0.228 \\
\hline Mean & 1.493 & 1.570 & 1.102 & & 0.247 & 0.211 & 0.166 & \\
\hline LSD at $0.05 \%$ & \multicolumn{4}{|c|}{$\begin{array}{c}\text { HAM: } 0.126 \\
\text { Interaction: } \\
0.219\end{array}$} & \multicolumn{4}{|c|}{$\begin{array}{l}\text { HAM: } 0.027 \text { Salt: } 0.023 \\
\text { Interaction: } 0.046\end{array}$} \\
\hline
\end{tabular}

HA: Humic acid. AMF: Arbuscular mycorrhizal fungi. HAM: Humic acid and /or Arbuscular mycorrhizal

Control: 320 ppm, Conc.1: 2000 ppm, Conc.2: 4000 ppm

ameliorated the adverse effect of salinity stress on photosynthetic pigments in the leaves of pepper plant. HA + mycorrhiza treatment was most effective in this respect. Hither, the mycorrhizal colonization significantly improved chlorophyll concentration. This is because $\mathrm{NaCl}$ has an antagonistic effect on $\mathrm{N}$ absorption which is an essential component of the structure of chlorophyll molecule.

Concerning the effect of salt stress levels and soil application with HA as bio stimulants and mycorrhiza as symbiosis agents on proline accumulation and catalase and peroxidase activities in leaves of pepper plants as shown in Table 4, it could be noticed that all salinity stress levels (2000 ppm and $4000 \mathrm{ppm}$ ) slightly increased proline accumulation, catalase and peroxidase activities in leaves of pepper plants.
Changes were incrementally related to the increase in salt stress. On the other hand, the treatment with humic acid and Mycorrhiza alone or in combination, increased proline content, catalase and peroxidase activities in leaves of pepper plant. It could be shown from the results that HA and mycorrhiza mitigated the harmful effect of salinity stress and also promoted proline accumulation, catalase and peroxidase activities in leaves of pepper plants. Moreover, $\mathrm{HA}+$ mycorrhiza treatment was most effective in this concern.

It could be seen the importance to ameliorate the negative impact of salt stress on pepper plants by using soil treated with humic acid and mycorrhiza. Humic acid which had protective enzymes activity, as one of the protection mechanisms by inhibiting or quenching free 
Table 4. Effect of humic acid and arbuscular mycorrhizal fungi (AMF) and their combination on Proline, Catalase and Peroxidase activities of pepper plant under salinity stress (average of two growing seasons 2014 and 2015)

\begin{tabular}{|c|c|c|c|c|c|c|c|c|c|c|}
\hline & \multicolumn{10}{|c|}{ Salinity levels } \\
\hline & Control & Conc.1 & Conc. 2 & Mean & Control & Conc.1 & Conc. 2 & Mean & Control & Conc.1 Conc.2 Mean \\
\hline & \multicolumn{4}{|c|}{ Proline (mg/g Dw) } & \multicolumn{4}{|c|}{ Catalase } & & Peroxidase \\
\hline$\overline{\text { Control }}$ & 5.335 & 14.320 & 16.730 & 12.128 & 58.875 & 208.945 & 305.45 & 191.090 & 15.045 & 31.96547 .61531 .542 \\
\hline HA & 9.345 & 15.070 & 17.285 & 13.900 & 76.075 & 211.210 & 377.84 & 221.710 & 18.205 & 34.01044 .02532 .080 \\
\hline AMF & 12.160 & 15.945 & 17.715 & 15.273 & 110.475 & 242.405 & 464.38 & 272.420 & 20.250 & 37.19547 .42034 .955 \\
\hline $\mathbf{H A}+\mathbf{A M F}$ & 13.595 & 16.245 & 17.710 & 15.850 & 153.450 & 294.280 & 503.56 & 317.097 & 22.510 & 39.48560 .70040 .898 \\
\hline Mean & 10.109 & 15.395 & 17.360 & & 99.719 & 239.210 & 412.80 & & 19.003 & 35.66449 .940 \\
\hline LSD at $0.05 \%$ & $\mathrm{HM}$ & $\begin{array}{l}\text { HAM: } \\
\text { Intera }\end{array}$ & $\begin{array}{l}0.211 \\
\text { action: } 0 .\end{array}$ & $\begin{array}{l}\text { Salt: } 0 \\
.367\end{array}$ & & $\begin{array}{r}\text { HM HAI } \\
\text { Inte }\end{array}$ & $\begin{array}{l}\text { M: } 32.6 \\
\text { eraction: }\end{array}$ & $\begin{array}{l}\text { 61 Salt : } \\
: 56.49\end{array}$ & $28.24 \mathrm{H}$ & $\begin{array}{l}\text { HAM: } 3.98 \text { Salt: } 3.455 \\
\text { Interaction: } 6.91\end{array}$ \\
\hline
\end{tabular}

HA: Humic acid. AMF: Arbuscular mycorrhizal fungi. HAM: Humic acid and /or Arbuscular mycorrhizal Control: 320 ppm, Conc.1: 2000 ppm, Conc.2: 4000 ppm

radicals. It is concluded that humic acid may play a significant role in the response to salinity and protection is largely through enzymatic processing of activated forms of oxygen.

It's evident that salinity stress levels increased proline content in leaves of pepper plant averaged during the two growing seasons. Several functions are proposed for the proline accumulation in tissues submitted to stress including osmotic adjustment, stabilization of proteins and cell membranes, being a scavenger of free radicals, improvement of the stability of some cytoplasmic and mitochondrial enzymes, and increased protection of proteins and enzymes. (Ozdemir et al., 2004 ; Sakr et al., 2007). On the growth parameters of cowpea, Hashem et al. (2015) reported that, AMF ameliorated the negative influence of salinity stress which enhanced the activity of catalase (CAT), peroxidase (POD), thus strengthening the defense system of plants. Proline accumulation is thought to be an adaptive feature under salinity stress in AM (Jindal et al., 1993). Arbuscular mycorrhizal plants enhance the activity of antioxidant enzymes in order to cope with the reactive oxygen species generated by salinity (Porcel et al., 2012).

The results in Table 5 clearly show the effect of salt stress and soil application with HA and mycorrhiza on N P K and $\mathrm{Na}$ in shoot pepper plants. All salinity stress (2000 and 4000 ppm) caused a significant reduction in nutrients percentage $\mathrm{N} \quad \mathrm{P} \quad \mathrm{K}$ while $\mathrm{Na}$ percentage increased. On the other hand, applied humic acid and mycorrhiza alone or in combination increased N P K while Na was decreased in shoot of pepper plant.

The results also showed that, salinity stress levels decreased potassium and increased sodium contents in the shoots of pepper plants which is a typical response of plants in saline conditions arising from the inability of plants to distinguish between potassium and sodium ions (Storey et al., 1983). In the vacuole, increasing $\mathrm{Na}^{+}$content mainly provides an osmotic adjustment of salt affected plants (Sakr et al., 2007). This accumulation might be due to the important role of sodium in increasing osmotic pressure.

Bio-stimulants can alleviate the adverse effect of drought or salinity stress through improving leaf water status and possibly by reduced uptake of ions $\mathrm{Na}$ and $\mathrm{Cl}$ (Nabati, 1994) and as a consequence increase $\mathrm{Ca}$ and $\mathrm{K}$ content in the leaves stimulating chloroplast development and enhancing phloem loading and delaying senescence (Demir et al., 2004).

Also, humic acid has been shown to increase the permeability of plant membranes, promoting the uptake of nutrients $\mathrm{N}, \mathrm{P}, \mathrm{K}, \mathrm{Ca}$, and $\mathrm{Mg}$ 
Table 5. Effect of humic acid and arbuscular mycorrhizal fungi (AMF) and their combination on $N, P, K$ and Na percentage of pepper plant under salinity stress (average of two growing seasons 2014 and 2015)

\begin{tabular}{|c|c|c|c|c|c|c|c|c|}
\hline & \multicolumn{8}{|c|}{ Salinity levels } \\
\hline & Control & Conc.1 & Conc.2 & Mean & Control & Conc.1 & Conc.2 & Mean \\
\hline & \multicolumn{4}{|c|}{ Nitrogen (N\%) } & \multicolumn{4}{|c|}{ Phosphorus (P\%) } \\
\hline Control & 2.310 & 1.905 & 1.239 & 1.818 & 0.410 & 0.299 & 0.189 & 0.299 \\
\hline HA & 2.454 & 2.020 & 1.350 & 1.941 & 0.442 & 0.327 & 0.198 & 0.322 \\
\hline AMF & 2.410 & 2.100 & 1.594 & 2.035 & 0.479 & 0.362 & 0.229 & 0.357 \\
\hline HA + AMF & 2.502 & 2.314 & 1.735 & 2.183 & 0.487 & 0.385 & 0.237 & 0.369 \\
\hline Mean & 2.419 & 2.085 & 1.479 & & 0.455 & 0.343 & 0.213 & \\
\hline LSD at $0.05 \%$ & \multicolumn{4}{|c|}{ HAM: $0.075 \quad$ Salt: 0.065} & & \multicolumn{3}{|c|}{$\begin{array}{l}\text { Interaction: } 0.004 \\
\text { Sodium (Na\%) }\end{array}$} \\
\hline Control & 2.920 & 2.295 & 2.020 & 2.412 & 1.145 & 1.630 & 1.995 & 1.590 \\
\hline HA & 3.305 & 2.705 & 2.115 & 2.708 & 1.130 & 1.420 & 1.945 & 1.498 \\
\hline AMF & 3.420 & 2.785 & 2.225 & 2.810 & 1.090 & 1.255 & 1.825 & 1.390 \\
\hline $\mathbf{H A}+\mathbf{A M F}$ & 3.470 & 2.915 & 2.265 & 2.883 & 0.970 & 1.200 & 1.715 & 1.295 \\
\hline Mean & 3.279 & 2.675 & 2.156 & & 1.084 & 1.376 & 1.870 & \\
\hline LSD at $0.05 \%$ & \multicolumn{4}{|c|}{$\begin{array}{c}\text { HAM: } 0.040 \quad \mathrm{Sa} \\
\text { Interaction: } 0.070\end{array}$} & \multicolumn{4}{|c|}{ Interaction: 0.066} \\
\hline
\end{tabular}

HA: Humic acid. AMF: Arbuscular mycorrhizal fungi. HAM: Humic acid and /or Arbuscular mycorrhizal Control: 320 ppm, Conc.1: 2000 ppm, Conc.2: 4000 ppm

(Mackowiak et al., 2001) and enhancing root development (Vaughan and Macdonald, 2005). Humic acids also are claimed to ions of chelate sodium in the soil which helps plants tolerate higher soil sodium concentrations avoiding toxicity and osmotically related problems (Super, 2006). It is also possible that these biostimulants are capable of stimulating the genetic pathways leading to improve plant defense mechanisms evidenced by the improved end product enhancement of antioxidants.

The results provide support for the field application of exogenous protectants as HA under salt stress condition has been found to be very much effective to alleviate salt- induced damages in pepper plants, according to Saker et al. (2015). Major reason for the increase in the growth and yield can be attributed to ability of plants in associations with AMF to uptake some nutrients efficiently, such as phosphorous. (Demir, 2004). These positive impacts are explained by improved host plant nutrition, higher $\mathrm{K}+/ \mathrm{Na}+$ ratios in plant tissues and a better osmotic adjustment by accumulation of compatible solutes such as soluble sugars, glycine betaine, or proline. (Porcel et al., 2012)

\section{Conclusion}

In the present study, salinity resulted in altered growth of pepper plants (C. annuum L.) $\mathrm{cv}$ top star due to its effects on the various physiological and biochemical parameters studied. It is possible to reduce the harmful effects of salinity stress by the application of humic acid as bio-stimulants and mycorrhiza as symbiosis agents to ameliorate the negative impact of salinity. 
AMF allayed the salt stress by preventing the excess uptake of $\mathrm{Na}+$ and at the same time causing further enhancement in activities of catalase and peroxidase enzymes, thus ensuring better scavenging of ROS. Besides this AMF and humic acid also increased proline accumulation, activities of enzymes as well as the uptake of mineral elements which have direct effect on the osmoregulation of the plants. Thus, the harmful effects of salinity on growth, antioxidant enzymes and mineral nutrients in pepper plants can be alleviated by AMF and Humic acid and their combination application.

Therefore, it is advisable that the dual application of HA and mycorrhiza could be an adequate strategy to alleviate the deleterious effects of salinity stress and promote much more growth and yield in pepper plants (Capsicum annuит L.) cv top star grown in salty condition.

\section{REFERENCES}

Ahanger, M.A., A. Hashem, E.F. Abd Allah and P. Ahmad (2014). Arbuscular mycorrhiza in crop improvement under environmental stress, In: Ahmad, P., Rasool, S. (Eds.), Emerging Technologies and Management of Crop Stress Tolerance, 2 : 69-95.

Al-Sobhi, O.A., H.S. Al-Zahrani and S.B. AlAhmadi (2006). Effect of salinity on chlorophyll and carbohydrate contents of Calotropis procera seedlings. Sci. J. King Faisal Univ., Basic and Appl. Sci., 7: 105-115.

Arafa, A.A., M.A. Khafagy, A.M. Abo-El Kheer and M.F. El-Banna (2014). Response of certain phytochemical constituents in sweet pepper leaves to some Bio-stimulants under two types of salinity. J. Adv. in Nat. Sci., 2 (2): 83-99.

Aroca, R., J.M. Ruiz-Lozano, A. Zamarreno, J.A. Paz, J.M. Garcia-Mina, M.J. Pozo and J.A. Lopez-Raez (2013). Arbuscular mycorrhizal symbiosis influences strigolactone production under salinity and alleviates salt stress in lettuce plants. J. Plant Physiol., 170 : $47-55$.

Bates, L., R.P. Waldren and I.D. Teare (1973). Rapid determination of free proline for water-stress studies. Plant and Soil, 39: 205207

Beltrano, J., M. Ruscitti, M.C. Arango and M. Ronco (2013). Effects of arbuscular mycorrhiza inoculation on plant growth, biological and physiological parameters and mineral nutrition in pepper grown under different salinity and $\mathrm{p}$ levels. J. Soil Sci. and Plant Nut., 13 (1): 123-141.

Chance, B. and A.C. Maehly (1955) Assay of Catalase and Peroxidase. Methods in Enzymol., 2: 764-775.

Chutipaijit, S., S. Chaum and K. Sompornpailin (2011). High contents of proline and anthocyanin increase protective response to salinity in Oryza sativa L. spp. indica. Aust. J Crop Sci., 5:1191-1198

Clapp, C.E., Y. Chen, M. Hayes, A.J. Palazzo and V.W. Cline (2002). Stimulation of plant growth by humic substances. World Cong. Soil Sci., 192.

Demir, D., A. Günes, A. Inal and M. Alpaslan (2014). Effects of humic acids on the yield and mineral nutrition of cucumber (Cucumis sativus L.) grown with different salinity levels. Acta Hort., 492:95-104

Demir, S. (2004). Influence of arbuscular mycorrhizae (AM) on some physiological growth parameters of pepper. Turkish $\mathrm{J}$. Biol., 28 : 85-90.

Dolatabadian, A., S.A.M. Modarressanavy and F. Ghanati (2011). Effect of salinity on growth, xylem structure and anatomical characteristics of soybean. Not. Sci. Biol., 3: 41- 45 .

Fahramand (2014). Influence of abiotic stress on proline, Photosynthetic enzymes and growth. Intl. Res. J. Appl. Basic. Sci., 8 (3) : 257-265

Gomez, K.A. and A.A. Gomez (1984). Statistical Procedures for Agricultural Research. $2^{\text {nd }}$ Ed., Wiley and Sons, New York. USA.

Hanafy, A.A.H., M.R. Nesiem, A.M. Hewedy and H.E.I-S. Sallam (2010). Effect of some simulative compounds on growth, yield and chemical composition of snap bean plants grown under calcareous soil conditions. J. Ame. Sci., 6 (10): 552-569. 
Hasanuzzaman, M., M.A. Hossain, J.A.T. da Silva and M. Fujita (2012). Plant responses and tolerance to abiotic oxidative stress: antioxidant defenses is a key factors. In: Bandi V, Shanker AK, Shanker C, Mandapaka M (eds) Crop stress and its management: perspectives and strategies. Springer, Berlin, 261-316.

Hashem, A., E.F. Abd-Allah, A.A. Alqarawi and D. Egamberdieva (2015). Induction of salt stress tolerance in cowpea [Vigna unguiculata (L.) Walp.] by arbuscular mycorrhizal fungi. Legume Res., 38 (5) : 579-588.

Jindal, V., A. Atwal, B.S. Sekhon and R. Singh (1993). Effect of vesicular-arbuscular mycorrhizae on metabolism of moong plants under $\mathrm{NaCl}$ salinity. Plant Physiol. and Biochem., 3: 475-481.

Kijne, J.W. (2003). Unlocking the Water Potential of Agriculture. FAO Corporate Document Repository, 70, ISBN 9251049114.

Mackowiak, L., P.R. Gross and B.G. Bugbee (2001). Beneficial Effects of humic acid on micronutrient availability to wheat. Soil Sci. Soc. Ame. J., 65: 1744-1750.

Martinez, A.S., F.D. Amor, M.I. Fortea, C.L. Abellan, S.L. Miranda and E.N. Delicado (2014). Effect of plant age and saline water on antioxidants and peroxidase activity in sweet pepper Fruit. J. Agric. Sci., 6 (12): 139-151.

Martínez, A.S., M.I. Fortea, F.M. Del Amor, C. Lucas-Abellán, M.T. Mercader-Ros, J.A. Gabaldón, A. Martínez-Cachá and E.N. Delicado (2015). Parameters of pepper fruit quality. Trends in Food Technol., 75-98.

Nabati, D.A. (1994). Responses of two grass species to plant regulators, fertilizer $\mathrm{N}$, chelated $\mathrm{Fe}$, salinity and water stress. Ph.D. Crop and Soil Environ. Sci. Dept., Virginia Tech, Blacksburg.

Naguib, M.I. (1963). Effect of colochicine of the nitrogen metabolism and fate of phosphorus observed during the formation of fungal of cunninghamella spp. Arch. Microbiol., 47: $154-160$.
Nardi, S., D. Pizzeghello, M. Schiavon A. Ertani (2016). Plant bio stimulants: physiological responses induced by protein hydrolyzedbased products and humic substances in plant metabolism. Sci. Agric., 73 (1): 18-23.

Ozdemir, O., B. Melike, D. Tije and T. Ismail (2004). Effects of 24-epibrassinolide on seed germination, seedling growth, lipid peroxidation, proline content and antioxidative system of rice (Oryza sativa L.) under salinity stress. Plant Growth Regulation, 42: 203-211.

Paridam, A.K. and A.B. Das (2005). Salt tolerance and salinity effects on plants: a review. Ecotoxicol. and Environ. Safety, 60: 324-349.

Peterburgski, A.V. (1968). Handbook of Agronomic Chemistry. Kolop Publishing House, Moscow, Russia.

Porcel, R., R. Aroca and J.M. Ruiz-Lozano (2012). Salinity stress alleviation using arbuscular mycorrhizal fungi. A Rev. Agron. Sustain. Dev., 32:181-200.

Rao, D.L.N. (1998). Biological amelioration of Salt affected Soils. In: Microbial Interactions in Agricultural and Forestry, Sci., Publ., Enfield, USA., $1: 221-238$.

Rouphael, Y., P. Franken, C. Schneider, D. Schwarz, M. Giovannetti, M. Agnolucci, S. De Pascale, P. Bonini and G. Colla (2015). Arbuscular mycorrhizal fungi act as biostimulants in horticultural crops. Scientia Hort., 196: 91-108.

Saha, P., P. Chatterjee and A. Biswas (2010). $\mathrm{NaCl}$ pretreatment alleviated salt stress by enhancement of antioxidant defense system and osmolyte accumulation in mungbean (Vigna radiata L. Wilczek). Ind. J. Exp. Bio., 48: 593-600.

Saker, M.T., N.M. El-Sarkassy and M.P. Fuller (2012). Exogenously applied antioxidants and biostimulants alleviate salt stress in sweet pepper. Zagazig J. Agric. Res., 39 (4): 605 617

Sakr, M.T., M. El-Hadidy, A.M. Abo El-Kheer and S. Farouk (2004). Physiological studies of some osmo-regulator on kanulla. International conversation microbiology and 
biotechnology in Africa and Arab Regions, $27^{\text {th }}$ to $29^{\text {th }}, 295-321$.

Sakr, M.T., M.E. El-Emery, R.A. Fouda and M.A. Mowafy (2007). Role of some antioxidants in alleviating soil salinity stress. J. of Agric. Sci., Mansoura Univ., 32: 97519763.

Sakr, M.T., N.M. El-Sarkassy and M.P. Fuller (2015). Minimization the effects of salt stress on sweet pepper plants by exogenous protectants application. Zagazig J. Agric. Res., 42 (6)-1397-1410

Selvakumar, G. and P. Thamizhiniyan (2011). The effect of the arbuscular mycorrhizal (AM) fungus (Glomus intraradices) on the growth and yield of Chilli (Capsicum annuum L.) under salinity stress. World Appl. Sci. J., 14 (8): 1209-1214.

Sharma, P.K. and D.O. Hall (1991). Interaction of salt stress and photo -inhibition on photosynthesis in barley and sorghum. J. Plant Physiol., 138: 614-619.

Shekoofeh, E. and H. Sepideh (2011). Effect of mycorrhizal fungi on some physiological characteristics of salt stressed Осітит basilicum L. Iraninan. J. Plant Physiol., 1(4): 215-222.

Sheng, M., M. Tang, F. Zhang and Y. Huang (2011). Influence of arbuscular mycorrhiza on organic solutes in maize leaves under salt stress. Mycorrhiza., $21: 423-430$
Smith, S.E. and D.J. Read (2008). Mycorrhizal Symbiosis. Academic Press, Inc., San Diego, USA

Snell, F.D. and C.T. Snell (1954). In: Colorimetric methods of analysis $3^{\text {rd }}$ Ed. D.Van Nostrand Company. New York, 512 (513): 516-518.

Storey, R., M.G. Pitan and R. Stelzer (1983). XRay Microanalysis of cells and cell compartments of Atriplex spongiosa root. J. Exp. Bot., 34: 1196-1206.

Super, G.R. (2006). How Does Fulvic Acid Affect Plant Permeability?

Tavakkoli, E., P. Rengasamy and G.K. McDonald (2010). High concentrations of $\mathrm{Na}^{+}$and $\mathrm{Cl}^{-}$ions in soil solution have simultaneous detrimental effects on growth of faba bean under salinity stress. J. Exp. Bot., 61:4449-4459

Thomas, R.L., J.J. Jen and C.V. Morr (1982). Changes in soluble and bound peroxidaseIAA oxidase during tomato fruit development. J. Food Sci., 47: 158-161.

Vaughan, D. and I.R. Macdonald (2005). Effects of humic acid on protein synthesis and ion uptake in beet. J. Exp. Bot., 22 (2): 400-410.

Vitoria, A.P., P.J. Lea and R.A. Azevado (2001). Antioxidant enzymes responses to cadmium in radish tissues. Phytochem., 57: 701-710.

Wettestein, D. (1957). Chlorophyll-Lethal undder submink roskopische formivechoel der plastiden. Exp. Cell. Res., 12: 427 - 433. 


\title{
تحسين الإجهاد الملحي باستخذام حض الهيوميك والميكور هيزا في نباتات القلفل
}

\author{
ناصر محمد السركسي - سهام عبد العال ابراهيم ـ السيد محمد دسوقي حسن

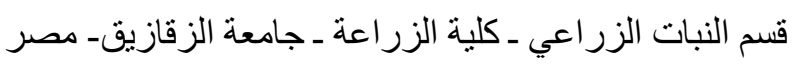

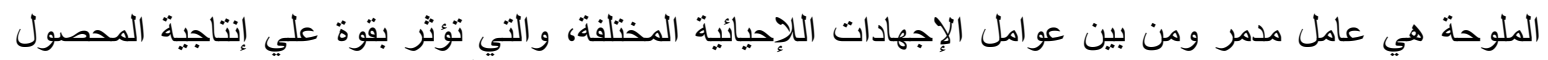

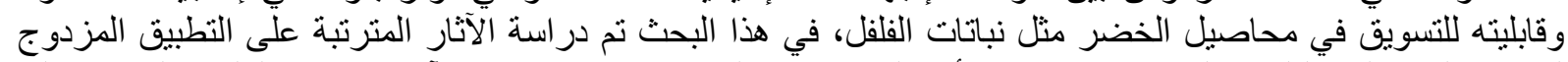

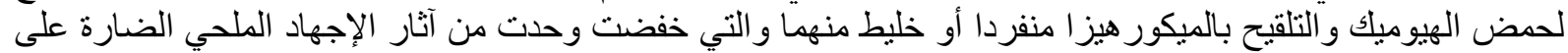

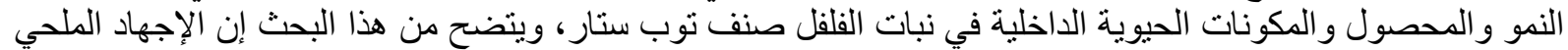

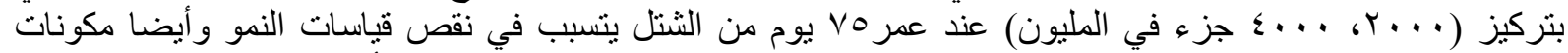

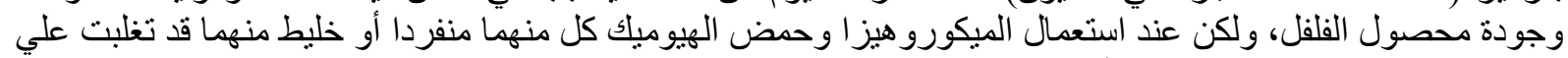

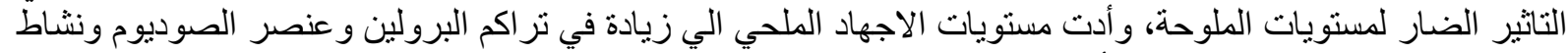

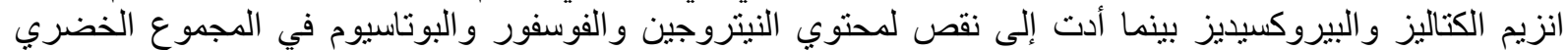

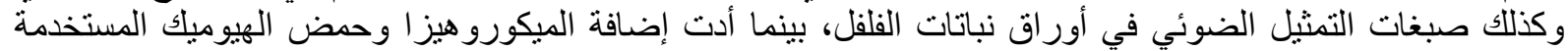

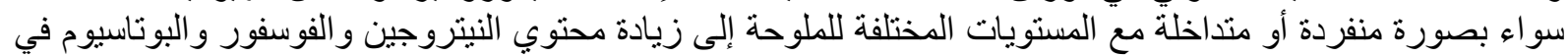

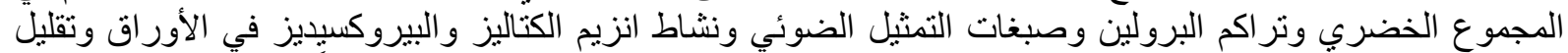

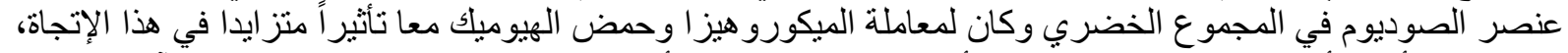

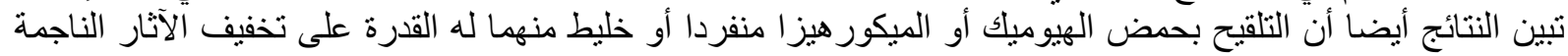

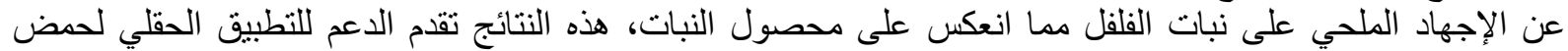
الهيو ميك و الميكورو هيز التقليل الآثار الضارة لملوحة التربة. 